\title{
О БАЛАНСЕ КАЛЬЦИЯ В ТРАВЯНЫХ ЭКОСИСТЕМАХ ТЕРСКО-КУМСКОЙ НИЗМЕННОСТИ ПРИКАСПИЯ
}

\author{
Г.Н. ГАСАНОВ1, 2 , Т.А. АСВАРОВА ${ }^{1}$, К.М. ГАДЖИЕВ 1 , Р.Р. БАШИРОВ 1 , \\ 3.Н. АХМЕДОВА' , А.С. АБДУЛАЕВА' 1 , Ш.К. САЛИХОВ ${ }^{1}$, Н.И. РАМАЗАНОВА', \\ А.Ш. ГИМБАТОВ 2 , М.Р. МУСАЕВ 2 , Н.Р. МАГОМЕДОВ 2,3 , Р.3. УСМАНОВ1
}

Терско-Кумская низменность занимает Северо-Западную часть Прикаспийской низменности. Почвенно-растительный покров территории определяется аридностью климата с частыми ветрами, наличием легких по гранулометрическому составу и засоленных почв, высокой пастбищной нагрузкой. В настоящем исследовании впервые дифференцированно определены продуктивность пастбищ Терско-Кумской низменности по структуре фитомассы (фотосинтезирующая масса, ветошь, степной войлок, корни), содержание и запасы кальция в благоприятный (апрель) и засушливый (август) периоды по сезонам года, рассчитан баланс Са в фитоценозах основных типов почв. Целью работы было определение объемов накопления, распределения и запасов кальция в структуре фитомассы для основных типов почв Терско-Кумской низменности. Исследования проводили на Кочубейской биосферной станции Прикаспийского института биологических ресурсов Дагестанского научного центра РАН в 2011-2016 годах. Объектами исследований были травяные фитоценозы на светло-каштановой и лугово-каштановой почвах и солончаке типичном автоморфном. Учет накопления растительного вещества за единицу времени на единице площади, содержания Са по элементам структуры (зеленая масса, ветошь, степной войлок, корни), а также расчет баланса Са в экосистемах выполняли по А.А. Титляновой с соавт. (1988). Содержание Са в растениях определяли при помощи системы капиллярного электрофореза Капель-105М («Люмэкс», Россия) со специализированным программным обеспечением Эльфоран («Люмэкс», Россия). Показано, что наибольшее количество фитомассы накапливалось на светло-каштановой почве. На лугово-каштановой почве фотосинтезирующей массы, ветоши, степного войлока и корней накапливалось меньше соответственно в 2,3, 1,5, 2,3 и 2,2 раза; на солончаке типичном - в 2,6, 1,7, 2,5 и 2,7 раза, чем на светло-каштановой. Возможно, это связано со снижением проективного покрытия с 77,0\% на светло-каштановой почве до 48,5 \% на лугово-каштановой и 43,5 \% на солончаке. В видовом составе фитоценозов на светло-каштановой почве преобладали представители Роасеае (51 \%), на лугово-каштановой - Asteraceae (30 \%), на солончаке типичном - также Asteraceae (17 \%). Масса корней на лугово-каштановой почве и солончаке типичном была в 2,2 и 2,9 раза меныше, чем на светло-каштановой почве. Их доля в суммарном урожае фитомассы по типам почв колебалась от 85,0 до 87,2 \%. В зеленой фитомассе содержание Са по сезонам года и типам почв находилось в пределах 0,40-0,48 \%, в ветоши $-0,50-054$, в войлоке $-1,00-1,31$, в подземных органах 1,14-1,38 \%. По типам почв оно снижалось в ряду светло-каштановая > лугово-каштановая $>$ солончак в связи с динамикой $\mathrm{pH}(8,6>8,2>8,0)$, увеличением степени засоления и смещением химизма засоления от сульфатного типа в сторону сульфатно-хлоридного. Запасы Са в надземной массе фитоценоза за вегетационный период на светло-каштановой почве составляли 2,32 кг/га в год и превышали аналогичные показатели на лугово-каштановой почве и солончаке типичном соответственно в 2,7 и 3,1 раза. Его запасы в корневой массе по всем типам почв были болыше, чем в надземной, в 12,6 раза. Из потребленного из почвы Са при разложении степного войлока обратно в светло-каштановую почву возвращалось 42,0 \%, подземных органов $-58,0 \%$; в лугово-каштановую почву - соответственно 36,0 и $64,0 \%$; в солончак типичный $-1,1$ - и 2,3-кратное количество. Выявлено, что различие в динамике накопления Са в структуре фитомассы полупустынных фитоценозов (фотосинтезирующая масса, ветошь, степной войлок, корни) зависит от видового состава, типа почвы и сезона года.

Ключевые слова: фитоценоз, накопление фитомассы, транслокация растительного вещества, концентрация Са, запасы Са, бюджет кальция.

\section{Для Терско-Кумская низменности (Северо-Западную часть Прика-} спийской низменности) характерны легкие по гранулометрическому составу и засоленные почвы, аридность климата, высокая пастбищная нагрузка, деградированность почвенного и растительного покрова. Почвы с низким содержанием гумуса и основных элементами питания растений в сочетании

*Работа выполнена при поддержке программы Президиума РАН № 1.21П «Биоразнообразие природных систем. Биологические ресурсы России: оценка состояния и фундаментальные основы мониторинга». 
с неблагоприятным водно-солевом режимом имеют низкую продуктивность (1). Однако эти оценки получены только для фотосинтезирующей части фитомассы, в то время как в структуре фитоценоза присутствуют и другие элементы - ветошь, степной войлок и корневая масса.

Исследования элементного состава фитоценозов Терско-Кумской низменности проводили многие авторы. В частности, имеются данные по относительному содержанию кальция в вегетирующей воздушно-сухой массе (сене) $(2,3)$, но нет аналогичных сведений с учетом структуры растительного покрова (зеленая масса, ветошь, войлок, корни). Отсутствие этих данных не позволяет судить о запасах биофильных элементов, в том числе Са, и оценить его баланс в травяных экосистемах, в том числе дифференцированно по основным типам почв.

На территории Терско-Кумской низменности содержание Са растениях больше, чем на прилегающей Присулакской низменности, $-2,014 \pm 0,02$ против 1,623 $\pm 0,25$ г/кг (4). При этом отмечают постепенное снижение его накопления с ноября по апрель следующего года. Г.И. Гиреев с соавт. (4) объясняют это трансформацией лугово-полынных сообществ в эфемерополынные и полынные. Можно предположить, что такое снижение количества Са в фитоценозах имеет другую причину и связано с транслокацией веществ между элементами структуры фитоценоза при смене фаз развития растений.

Отмечают, что решающее влияние на накопление химических элементов в растениях оказывает увлажненность, в частности содержание Са повышается по мере увеличения количества осадков $(5,6)$. Также выявлено, что благоприятные гидротермические условия в период вегетации растений служат фактором, способствующим повышению содержания Са в почве (7).

В настоящем исследовании в условиях Терско-Кумской полупустыни для основных типов почв дифференцированно (с учетом структуры фитомассы) оценена продуктивность травяных экосистем в связи с запасами Са в наиболее благоприятный по климатическим условиям (апрель) и засушливый (август) периоды года, а также рассчитан баланс Са в экосистемах.

Цель работы - изучить аккумуляцию кальция в растительном веществе с учетом его структуры и распределение этого элемента в травяных экосистемах на основных типах почв Терско-Кумской низменности.

Методика. Исследования проводили на Кочубейской биосферной станции Прикаспийского института биологических ресурсов Дагестанского научного центра РАН (ПИБР ДНЦ РАН, КБС, 44.40720 с.ш., 46.24771 в.д) в 2011-2016 годах. Содержание, запасы и бюджет кальция с учетом сезонов года (апрель, август) детально анализировали в 2013-2015 годах. Изучали травяные фитоценозы на светло-каштановой и лугово-каштановой почвах и солончаке типичном автоморфном Терско-Кумской низменности. Содержание гумуса в слое 0-30 см светло-каштановой почвы составляло $1,12 \%, \mathrm{P}_{2} \mathrm{O}_{5}-$

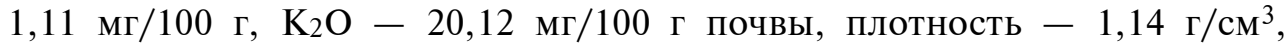
наименьшая влагоемкость - 20,6 \%; для лугово-каштановой эти показатели

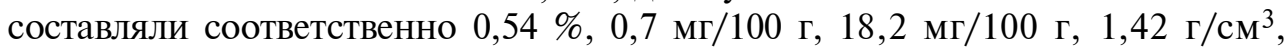
$26,7 \%$; для солончака типичного автоморфного - 0,48 \%; 0,66 мг/100 г;

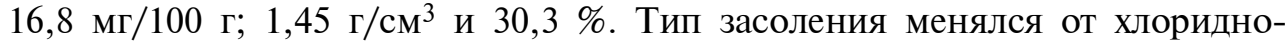
сульфатного до хлоридного в зависимости от гидротермических условий сезонов года, степень засоления - от слабой до очень сильной.

Учет накопления растительного вещества за единицу времени на единице площади, содержания Са в зеленой массе, ветоши, степном войлоке и корнях, а также расчет баланса Са в экосистемах проводили по 
А.А. Титляновой (7). Содержание Са в растительном веществе определяли методом капиллярного электрофореза (система Капель-105М, «Люмэкс», Россия) в режиме определения катионов и анионов со специализированным программным обеспечением Эльфоран («Люмэкс», Россия) (8). Всего проанализировали 150 проб в 3 биологических и аналитических повторностях.

Латинские названия видов приведены по Р.А. Муртазалиеву (9).

Статистическую обработку данных проводили в программе Microsoft Excel 2010. Рассчитывали средние величины $(M)$ и ошибки среднего ( $\pm \mathrm{SEM})$, уравнения линейной регрессии, коэффициент корреляции $(r)$, коэффициент детерминации (R).

Результаты. В условиях равнины наиболее продуктивны фитоценозы на светло-каштановой почве: в среднем за 2011-2016 годы накопление воздушно-сухой фитомассы здесь было в 2,2 раза выше, чем в случае лугово-каштановой почвы. На солончаке типичном автоморфном продуктивность фитоценоза снижалась в 2,6 раза по сравнению с таковой для светлокаштановой почвы (табл.).

На лугово-каштановой почве и солончаке типичном накапливалось столько же ветоши (соответственно 102,8 и 100,5 \%), сколько и зеленой массы, а на светло-каштановой почве - на 33,7 \% меныше, что было связано с видовым составом фитоценозов.

Накопление воздушно-сухой надземной и подземной фитомассы в структурных элементах растительного покрова и аккумуляция Са для разных типов почвы Терско-Кумской низменности (Кочубейская биосферная станция ПИБР ДНЦ РАН, 2011-2016 годы)

\begin{tabular}{|c|c|c|c|c|}
\hline \multirow[b]{2}{*}{$\begin{array}{l}\text { Растительное } \\
\text { вещество }\end{array}$} & \multirow[b]{2}{*}{ Тип почвы } & \multirow[b]{2}{*}{$\begin{array}{l}\text { Фитомасса, т/га в год } \\
(M \pm \mathrm{SEM})\end{array}$} & \multicolumn{2}{|c|}{$\mathrm{Ca}$} \\
\hline & & & $\begin{array}{l}\text { содержание, \% } \\
(M \pm \mathrm{SEM})\end{array}$ & запасы, кг/га \\
\hline \multirow[t]{3}{*}{ Зеленая масса } & Светло-каштановая & $4,84 \pm 0,02$ & $0,48 \pm 0,02$ & 2,32 \\
\hline & Лугово-каштановая & $2,11 \pm 0,01$ & $0,41 \pm 0,01$ & 0,86 \\
\hline & Солончак типичный & $1,89 \pm 0,03$ & $0,40 \pm 0,03$ & 0,76 \\
\hline \multirow[t]{3}{*}{ Ветошь } & Светло-каштановая & $3,21 \pm 0,02$ & $0,54 \pm 0,03$ & 1,73 \\
\hline & Лугово-каштановая & $2,17 \pm 0,01$ & $0,50 \pm 0,01$ & 1,08 \\
\hline & Солончак типичный & $1,91 \pm 0,04$ & $0,50 \pm 0,02$ & 0,96 \\
\hline \multirow[t]{3}{*}{ Войлок } & Светло-каштановая & $4,32 \pm 0,03$ & $1,31 \pm 0,01$ & 5,66 \\
\hline & Лугово-каштановая & $1,89 \pm 0,02$ & $1,30 \pm 0,02$ & 2,46 \\
\hline & Солончак типичный & $1,71 \pm 0,02$ & $1,00 \pm 0,01$ & 1,71 \\
\hline \multirow[t]{3}{*}{ Подземная масса } & Светло-каштановая & $83,71 \pm 0,03$ & $1,38 \pm 0,02$ & 115,52 \\
\hline & Лугово-каштановая & $38,19 \pm 0,03$ & $1,38 \pm 0,03$ & 52,70 \\
\hline & Солончак типичный & $31,19 \pm 0,02$ & $1,14 \pm 0,03$ & 35,56 \\
\hline
\end{tabular}

На светло-каштановой почве доля эфемеров из семейства мятликовых, которые были представлены полевичкой малой (Eragrostic minor Host.), мятликом луковичным (Poa bulbosa L.), мортуком восточным (Eremopyrum orientale L.), составляла 51,4 \% по количеству и 19,6 \% по массе. На луговокаштановой почве и солончаке фитомасса полыни таврической (Artemisia taurica Willd) и полыни Лерха (A. lercheana Web. ex Stechm) оставалась достаточно высокой (37,7 \% по количеству и 83,7 \% по массе), поскольку их ветошь за апрель-август не успевала полностью перейти в степной войлок.

По данным многих авторов, вклад подземных органов в общую массу травянистых фитоценозов составляет 50-90 \% $(10,11)$. В наших исследованиях масса корней на лугово-каштановой почве и солончаке типичном оказалась в 2,2 и 2,9 раза меньше, чем на светло-каштановой почве. Их доля в суммарном урожае фитомассы по типам почв колебалась от 85,0 до $87,2 \%$. Такое высокое соотношение надземной и подземной массы $(1: 6,8-1: 5,7)$ характерно для всех засушливых регионов мира $(12,13)$. 
По нашим данными, в условиях полупустыни связь между накоплением надземной $(x)$ и подземной $(y)$ массы у растений в экосистемах в зависимости от типа почв описывали следующие уравнения регрессии:

на светло-каштановой $y=0,6935 x+73,7823(r=0,97, \mathrm{R}=0,96)$;

на лугово-каштановой $y=1,1804 x+30,7254(r=0,96, \mathrm{R}=0,95)$;

на солончаке типичном $y=1,7925 x+21,0415(r=0,97, \mathrm{R}=0,95)$.

Основной причиной снижения сборов фитомассы на лугово-каштановой почве и солончаке типичном становится усиление засоления почвы и изменение его характера в сторону увеличения соотношения ионов $\mathrm{Cl}^{-}: \mathrm{SO}_{4}{ }^{2-}$ (11). Следует отметить, что продуктивность травяных экосистем Терско-Кумской низменности была значительно ниже, чем в других регионах страны, где она составляет 15-20 т/га $(10,11)$. Только на светло-каштановой почве этот показатель приближался к нижнему из указанных пределов, а на лугово-каштановой почве и солончаке типичном оказался в 2,22,6 раза ниже. Аналогичные результаты получены другими авторами в районе проведения наших исследований (5), в Астраханской области (14), в условиях сухой и опустыненной степи Тувы $(12,13)$, в засушливых районах Ирана (15), Панамы (5), Китая (16), в регионах с аридным климатом.

В жизни растений Са играет важную роль в образовании клеточных оболочек, принимает участие в поддержании структуры хромосом, митохондрий и рибосом $(17,18)$, повышает солевую толерантность (19-21), устойчивость растений к тепловому стрессу (22) и негативному воздействию тяжелых металлов (23), оптимизирует рост и развитие корней (24).

Средние за 2013-2015 годы (апрель, август) показатели содержания Са в зеленой массе и других элементах структуры растительного покрова в целом соответствовали накопленному урожаю фитомассы и составляли на светло-каштановой почве $0,48 \%$, на лугово-каштановой $-0,41 \%$, на солончаке - 0,40\%. Были отмечены существенные различия в содержании элемента по видам растений. На светло-каштановой почве $51 \%$ от суммарного проективного покрытия (77 \%) приходился на злаковые - костер кровельный Anisantha tectorum (L.) Nevski, костер растопыренный Bromus squarrosus L., мятлик луковичный Poa bulbosa L., полевичку малую Eragrostis minor Host и мортук пшеничный Eremopyrum triticeum (Gaertn.) Nevski, $15 \%$ - на полыни Artemisia taurica Willd и A. lercheana Web. ex Stechm, $5 \%$ - на солянки, включая рогач песчаный Ceratocarpus arenarius L., coлянку грузинскую Salsola iberica Sennen \& Рau, петросимонию раскидистую Petrosimonia brachiata (Pall.) Bunge, $3 \%$ - на гвоздичные (смолевка коническая Silene conica L. и грыжник седой Herniaria incana Lam.) и $3 \%$ - на крестоцветные (бурачок пустынный Alussum desertorum Stapf.). Содержание кальция у сложноцветных (виды полыни) составляло 1,03\%, у маревых (солянки) $-0,93 \%$, у гвоздичных - 0,38\%, у крестоцветных $-0,22 \%$ и у злаковых - 0,58\%.

На лугово-каштановой почве проективное покрытие мятликовыми снижалось в 5,1 раза, гвоздичными - в 2,0 раза, крестоцветными - в 1,5 раза, тогда как полынями из семейства сложноцветных - увеличивалось в 2,0 раза. Несмотря на то, что на этом типе почв доля сложноцветных и маревых с высоким накоплением Са повышалась, среднее содержание элемента в группе мятликовых снижалось по сравнению с показателями, полученными на светло-каштановой почве, до 0,47 \%, у маревых - до 0,90 \% при незначительных отклонениях в фитомассе у других семейств. На солончаке типичном общее проективное покрытие фитоценозом (43,5 \%) 
приближалось к показателю на лугово-каштановой почве $(48,5$ \%), но содержание элемента снижалось только у солянок (на 0,24 \%) при относительно близких значениях в других группах растений.

Уменьшение содержания Са в фитомассе на почвах в ряду светлокаштановая > лугово-каштановая > солончак мы связываем с незначительным понижением рН почвенного раствора в этом же ряду $(8,6>8,2>8,0)$, что становится причиной более легкой доступности Са из почв, то же подтверждают и другие авторы (25). Кроме того, сказывается усиление засоления и переход от его сульфатного типа в сторону сульфатно-хлоридного (11). Эти факторы существенно снижают доступность Са для растений из лугово-каштановой почвы и солончака типичного по сравнению со светлокаштановым типом.

Известно, что поступление ионов различных металлов из почвы в корневую систему и надземные органы растений осуществляется за счет динамики осмотического давления с участием переносчиков, кодируемых различными генами (26). Роль типа почвы $(x)$ и видового состава фитоценозов $(y)$ в изменении концентрации Са $(z)$ описывало следующее уравнение: $z=0,1057-0,4999 x+1,1898 y$.

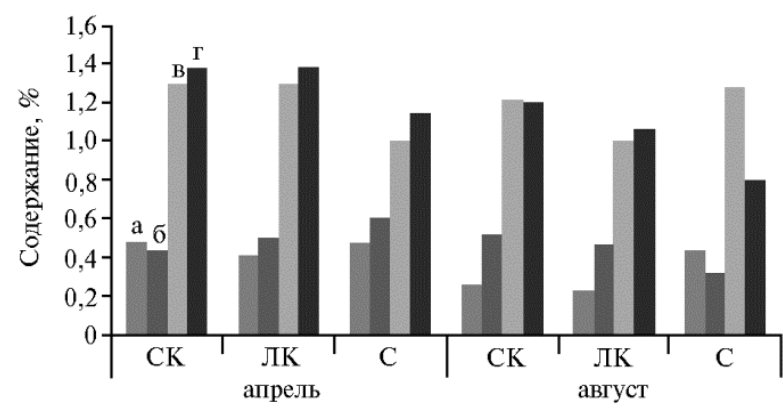

Рис. 1. Накопление Са в фитоценозах Терско-Кумской низменности в зависимости от типа почв и сроков определения: CK - светло-каштановая почва, ЛК - лугово-каштановая почва, С - солончак типичный; а - зеленая масса, б ветошь, в - войлок, г - подземные органы (Кочубейская биосферная станция ПИБР ДНЦ РАН, 2013-2015 годы).

В ветоши и войлоке содержание Са выравнивалось, а в подземных органах снижалось от $1,38 \%$ на двух первых типах почв до $1,14 \%$ на солончаке типичном (рис. 1). Достаточно высокое количество Са в фитомассе в условиях непромывного водного режима способствовало поддержанию в почвенном растворе нейтральной и слабощелочной реакции (10).

Запасы элемента в корневой массе на всех почвах были больше, чем в надземной, в среднем в 12,6 раза $(73,81$ кг/га против

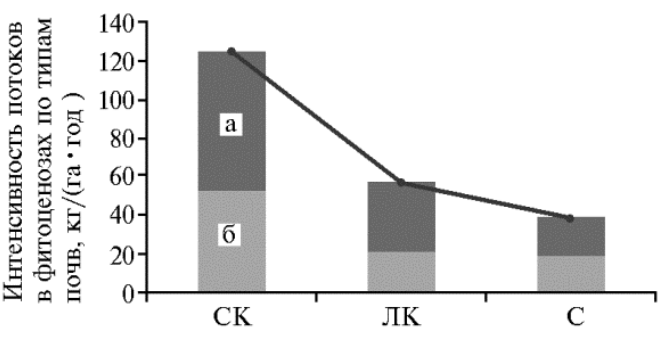

Рис. 2. Бюджет кальция в фитоценозах ТерскоКумской низменности в зависимости от типа почв: СК - светло-каштановая почва, ЛК - луговокаштановая почва, C - солончак типичный; а поступило в почву при разложении подземных органов, б - поступило в почву при разложении войлока; кривая - потреблено из почвы (Кочубейская биосферная станция ПИБР ДНЦ РАН, 2013-2015 годы).
5,85 кг/га). С учетом приведенных данных был составлен баланс Са в биогеоценозах рассматриваемых типов почв (рис. 2). В травяных экосистемах кальция потребляется значительно больше, чем в лесных (16). В наших исследованиях на светлокаштановой почве из потребленных фитоценозом 125,23 кг/га Са в год при разложении степного войлока в почву возвращалось 42,0 \%, подземных органов - 58,0 \%. На лугово-каштановой почве доля $\mathrm{Ca}$, поступившего при разложении войлока, снижалась до 36,8 \%, на солончаке типичном - увеличивалась до 48,4\%. 
Относительно высокая продуктивность фитоценозов на светло-каштановой почве способствует обогащению ее верхних горизонтов Са и другими биофильными элементами (Fe, $\mathrm{Si}, \mathrm{Al})$, которые служат основным фактором биосинтеза вторичных глинистых минералов, формирующих поглощающий комплекс почвы. Высокое содержание в фитомассе травянистых растений Са (наряду $\mathrm{Mg}$ и S) приводит к насыщению поглощающего комплекса почв Терско-Кумской низменности этим сильным коагулятором, обеспечивающим формирование благоприятных агрофизических свойств почвы и улучшение ее структуры (1).

На всех типах почв весной наблюдалось более высокое содержание Са по сравнению с летним периодом (I декада августа), что объясняется благоприятным водным режимом почвы в этот период, способствующим поступлению химических элементов в растения. Снижение количества Са в августе связано с увеличением засоленности почвы, ростом осмотического давления почвенного раствора и замедлением поступления почвенной влаги и питательных элементов в растения. Эти данные подтверждают справедливость вывода о том, интенсивность поступления химических элементов, включая Са, в растения связана с благоприятными гидротермическими условиями (10), а не с трансформацией лугово-полынных сообществ в эфемерополынные и полынные $(3,4)$.

Еще одна причина снижения накопления Са в пастбищных фитоценозах к концу вегетационного периода или к весне следующего года - отток части элементов из стареющих и отмирающих растительных тканей в молодые или вновь формируемые. По мнению А.А. Титляновой (10), процесс ретранслокация питательных элементов универсален и присущ всем экосистемам. Следовательно, на основных типах изученных почв достаточное содержание Са в фитомассе, а в последующем его поступление в верхнюю часть почвенного профиля становится основой биологических циклов Са в травяных ценозах.

Таким образом, максимальные запасы фотосинтезирующей фитомассы $\left(4,84 \mathrm{\kappa г} \cdot \mathrm{ra}^{-1} \cdot\right.$ год $\left.{ }^{-1}\right)$, ветоши $\left(3,21 \mathrm{\kappa г} \cdot \mathrm{ra}^{-1} \cdot\right.$ год $\left.{ }^{-1}\right)$, степного войлока $\left(4,32\right.$ кг $\cdot$ га $^{-1} \cdot$ год $\left.^{-1}\right)$ и корней $\left(83,71 \mathrm{Kг} \cdot\right.$ га $^{-1} \cdot$ год $\left.^{-1}\right)$ на Терско-Кумской низменности накапливались на светло-каштановой почве. На лугово-каштановой почве эти показатели снижались соответственно в 2,3; 1,5; 2,3 и 2,2 раза, на солончаке типичном - в 2,6; 1,$7 ; 2,5$ и 2,7 раза. Накопление Са в надземной и подземной массе соответствовала урожайности фитоценозов. В зеленой массе его содержание составляло в среднем 0,48-0,40 \%, в войлоке $-1,0-1,3 \%$, в подземных органах $-1,14-1,38 \%$. Максимальные запасы элемента в надземной массе растений за вегетационные периоды накапливались на светло-каштановой почве $\left(9,71 \mathrm{Kг}^{\cdot} \mathrm{ra}^{-1} \cdot\right.$ сут $\left.^{-1}\right)$, превышая аналогичные показатели на лугово-каштановой почве и солончаке типичном соответственно в 2,7 и 3,1 раза. На светло-каштановой почве при разложении степного войлока в почву возвращалось 42,0 \% потребленного Са, на лугово-каштановой $-36,0 \%$, на солончаке типичном $-48,4 \%$. Такое же его количество перемещалось в надземные органы. При разложении подземных органов в растения поступало соответственно по типам почв 58,0; 64,0 и 51,6 \% Са. Выявлено, что различие в динамике накопления Са в структуре фитомассы (фотосинтезирующая масса, ветошь, степной войлок, корни) полупустынных фитоценозов зависит от видового состава, типа почвы, сезона года. 
367000 Россия, Республика Дагестан, г. Махачкала, ул. М. Гаджиева, 45,

e-mail: nikuevich@mail.ru $\bowtie$, tatacvar@mail.ru, kamil5555372@mail.ru, pakduik100@mail.ru, zaira-1945@mail.ru, aischat55@mail.ru,

salichov72@mail.ru, nurjagan@yandex.ru, pibrdncran@mail.ru;

\title{
2ФГБОУ ВО Дагестанский государственный
}

аграрный университет им. М.М. Джамбулатова,

367000 Россия, Республика Дагестан, г. Махачкала, ул. М. Гаджиева, 45,

e-mail: daggau@list.ru, zaremka_76@mail.ru, musiska2014@mail.ru;

${ }_{3}$ ФББНУ Федеральный аграрный научный центр

\section{Республики Дагестан,}

367014 Россия, Республика Дагестан, г. Махачкала, ул. А. Шахбанова, 30,

e-mail: musiska2014@mail.ru

\section{THE BALANCE OF CALCIUM IN THE GRASS ECOSYSTEMS OF THE TEREK-KUMA LOWLAND}

\author{
G.N. Gasanov', 2, T.A. Asvarova1, K.M. Hajiyev', R.R. Bashirov', Z.N. Akhmedova1, \\ A.S. Abdulaeval, Sh.K. Salikhov', N.I. Ramazanoval, A.Sh. Gimbatov', M.R. Musaev', \\ N.R. Magomedov'2, 3, R.Z. Usmanov ${ }^{1}$
}

\begin{abstract}
1Precaspian Institute of Biological Resources, Dagestan Science Centre RAS, 45, ul. M. Gadjieva, Makhachkala, Republic of Dagestan, Russia 367000, e-mail nikuevich@mail.ru ( $\bowtie$ corresponding author), tatacvar@mail.ru, kami15555372@mail.ru, pakduik100@mail.ru, zaira-1945@mail.ru, aischat55@mail.ru, salichov72@mail.ru, nurjagan@yandex.ru, pibrdncran@mail.ru;

${ }^{2}$ Dzhambulatov Dagestan State Agricultural University, 180, ul. M. Gadjieva, Makhachkala, Republic of Dagestan, Russia 367000, e-maildaggau@list.ru, zaremka_76@mail.ru,musiska2014@mail.ru;

${ }^{3}$ Federal Agrarian Research Center of the Republic of Dagestan, 30, ul. A. Shahbanova, Makhachkala, Republic of Dagestan, Russia 367014, e-mail musiska2014@mail.ru
\end{abstract}

ORCID:

Gasanov G.N. orcid.org/0000-0002-6181-5196

Asvarova T.A. orcid.org/0000-0002-5285-9250

Hajiyev K.M. orcid.org/0000-0003-1150-9593

Bashirov R.R. orcid.org/0000-0002-6331-2592

Akhmedova Z.N. orcid.org/0000-0002-7141-939X

Abdulaeva A.S. orcid.org/0000-0001-9056-1909

The authors declare no conflict of interests

Acknowledgements:

Supported by the Presidium RAS program No. 112P "Biodiversity of natural systems. Biological resources of Russia: state assessment and fundamental principles of monitoring"

Received August 20, 2018

doi: $10.15389 /$ agrobiology.2020.3.597eng

\author{
Salikhov Sh.K. orcid.org/0000-0001-5531-3045 \\ Ramazanova N.I. orcid.org/0000-0001-9525-6292 \\ Gimbatov A.Sh. orcid.org/0000-0003-2801-2276 \\ Musaev M.R. orcid.org/0000-0002-3170-2086 \\ Magomedov N.R. orcid.org/0000-0003-3871-0932 \\ Usmanov R.Z. orcid.org/0000-0002-4046-5991
} A b s t r a t
Terek-Kuma lowland occupies the North-Western part of the Precaspian lowland. The soil-
plant cover of the territory is determined by the aridity of the climate with frequent winds, light
granulometric and saline soils, high pasture load. In this study, for the first time in the Terek-Kuma
semidesert conditions, the productivity of structural parts of grass ecosystems and calcium reserves
during the most favorable (April) and arid (August) periods are determined for the main soil types.
The work aimed to determine the accumulation, distribution and reserves of calcium in the structure
of phytomass with regard to a soil type. The research was performed at the Kochubey Biosphere
Station, Precaspian Institute of Biological Resources of the Dagestan Scientific Center RAS in $2011-$
2016 on grass phytocenoses of light chestnut and meadow-chestnut soils and saline typical automorphic
soils. Assessment of plant matter and Ca accumulation in green mass, rags, steppe felt, and roots, and
calculation of the Ca budget of the ecosystems were carried out according to A.A. Titlyanova et al.
(1988). The content of Ca in plants was determined by capillary electrophoresis (a Drops-105M system,
Lumex, Russia) with special software Elforan (Lumex, Russia). The greatest amount of phytomass
accumulated on light chestnut soil. On meadow-chestnut soil photosynthesizing parts, rags, steppe felt
and roots accumulated $2.3,1.5,2.3$ and 2.2 times less, respectively, and on typical saline soil 2.6 , 1.7 ,
2.5 and 2.7 times less than on light chestnut soil. This was likely caused by a decrease in projective
coverage from $77.0 \%$ on light chestnut soil to $48.5 \%$ on meadow chestnut soil and $43.5 \%$ on typical
saline soil. In the species patterns the dominants were Poaceae (51 \% for light chestnut soil) and
Asteraceae ( $30 \%$ and $17 \%$ for meadow chestnut soil and saline soil, respectively). The root weight for 
meadow-chestnut soil and typical saline soil was 2.2 and 2.9 times less than for light chestnut soil. Their share in the total phytomass depending on soil types ranged from 85.0 to $87.2 \%$. In green parts, the concentration of $\mathrm{Ca}$, depending on the season and the soil type, was in the range of 0.40 $0.48 \%$, in rags it was $0.50-0.54 \%$, in felt $1.00-1.31 \%$, and in underground parts $1.14-1.38 \%$. By soil types, it decreased as light chestnut soil $>$ meadow-chestnut soil $>$ saline soil due to $\mathrm{pH}$ changes $(8.6>8.2>8.0)$, an increase in the degree of salinity and the shift of salinity from the sulfate type to the sulfate-chloride type. Reserves of $\mathrm{Ca}$ in the above-ground parts during the growing season on light chestnut soil amounted to $2.32 \mathrm{~kg} / \mathrm{ha}$ per year and exceeded 2.7- and 3.1-fold, respectively, similar indicators for meadow-chestnut soil and typical saline soil. Ca reserves in the root mass for all types of soils were 12.6 times more than in the aboveground parts. After plant matter decomposition, steppe felt and underground organs contribute to light chestnut soil 42.0 and $58.0 \%$ of the calcium consumed from the soil, to meadow chestnut soil 36.0 and $64.0 \%$, respectively; for the typical saline soil these amounts are 1.1- and 2.3-fold, respectively. It was revealed that the difference in the dynamics of Ca accumulation in components of a semi-desert plant community (green mass, rags, steppe felt, and roots) depends on the plant species composition, soil type and season.

Keywords: phytocoenosis, phytomass accumulation, plant matter translocation, Ca accumulation, $\mathrm{Ca}$ reserves, calcium budget.

\section{RE F E R E N C ES}

1. Balamirzoev M.A., Mirzoev E.M.-R., Adzhiev A.M., Mufaradzhev K.G. Pochvy Dagestana. Ekologicheskie aspekty ikh ratsional'nogo ispol'zovaniya [Soils of Dagestan - environmental aspects of rational use]. Makhachkala, 2008 (in Russ.).

2. Usmanov R.Z., Osipova S.V., Dzhalalova M.I., Babaeva M.A. Yug Rossii: ekologiya, razvitie, 2008, 3(3): 109-111 (in Russ.).

3. Zagidova R.M., Biibolatova Z.D., Asgerova D.B., Abdurashidova P.A. Vestnik Dagestanskogo gosudarstvennogo universiteta, 2015, 30(1): 60-65 (in Russ.).

4. Gireev G.I., Luganova S.G., Salikhov Sh.K. Vestnik Tambovskogo universiteta. Seriya: Estestvennye i tekhnicheskie nauki, 2013, 18(3): 767-770 (in Russ.).

5. Santiago LS., Schuur EA., Silvera K. Nutrient cycling and plant-soil feedbacks along a precipitation gradient in lowland Panama. Journal of Tropical Ecology, 2005, 21(4): 461-470 (doi: 10.1017/s0266467405002464).

6. Dijkstraa F.A., Heb M., Johansenc M.P., Harrisonc J.J., Keitel C. Plant and microbial uptake of nitrogen and phosphorus affected by drought using ${ }^{15} \mathrm{~N}$ and ${ }^{32} \mathrm{P}$ tracers. Soil Biology and Biochemistry, 2015, 82: 135-142 (doi: 10.1016/j.soilbio.2014.12.021).

7. Titlyanova A.A., Bazilevich N.I., Snytko V.A., Dubynina S.S., Kopoteva T.A., Magomedova L.N., Mironycheva-Tokareva N.P., Nefed'eva L.G., Semenyuk N.V., Tishkov A.A., Ti Tran, Khakimzyanova F.I., Shatokhina N.G., Shmakova E.I. Biologicheskaya produktivnost' travyanykh ekosistem. Geograficheskie zakonomernosti i ekologicheskie osobennosti /Pod redaktsiei V.B. Il'inoi [Biological productivity of grassy ecosystems. Geographical patterns and environmental features. V.B. Il'ina (ed.)]. Novosibirsk, 1988: 109-127 (in Russ.).

8. Komarova N.V., Kamentsev Ya.S. Prakticheskoe rukovodstvo po ispol'zovaniyu sistem kapillyarnogo elektroforeza «KAPEL'» [Practical guide for using capillary electrophoresis systems «KAPEL'»]. St. Petersburg, 2006 (in Russ.).

9. Murtazaliev R.A. Konspekt flory Dagestana /Pod redaktsiei R.V. Kamelina [Outline of Dagestan flora. R.V. Kamelin (ed.)]. Makhachkala, 2009 (in Russ.).

10. Titlyanova A.A. Pochvovedenie, 2007, 12: 1422-1429 (in Russ.).

11. Gasanov G.N., Asvarova T.A., Gadzhiev K.M., Akhmedova Z.N., Abdulaeva A.S., Bashirov R.R., Arslanov M.A. Izvestiya Samarskogo nauchnogo tsentra RAN, 2016, 18(2): 59-64 (in Russ.).

12. Kurbatskaya S.S. Novye issledovaniya Tuvy, 2009, 4: 209-224 (in Russ.).

13. Titlyanova A.A., Sambuu A.D. Izvestiya RAN. Seriya biologicheskaya, 2014, 6: 621-630 (in Russ.).

14. Tyutyuma N.V., Bulakhtina G.K. Trudy instituta geologii Dagestanskogo nauchnogo tsentra RAN, 2016, 1: 68-72 (in Russ.).

15. Saffariha M., Azarnivand H., Tavili A. Effects of grazed exclosure on some of nutrient elements of aerial and underground organs of Artemisia sieberi, Stipa hohenacheriana and Salsola rigida. International Journal of Agronomy and Agricultural Research, 2014, 4(2): 62-70.

16. Zuo X.A., Knops J.M.H., Zhao X.Y., Zhao H.L., Li Y.Q., Guo Y.R. A positive correlation between plant diversity and productivity is indirectly caused by environmental factors driving spatial pattern of vegetation composition in semiarid sandy grassland. Biogeosciences Discussions, 2011, 8: 1795-1801.

17. Marschner's mineral nutrition of higher plants. 3rd edition. P. Marschner (ed.). Amsterdam, 
Netherlands, Elsevier/Academic Press, 2011 (doi: 10.1017/s001447971100130x).

18. Shen J., Yuan L., Zhang J., Bai Z., Chen X., Zhang W., Zhang F. Phosphorus dynamics: from soil to plant. Plant Physiology, 2011, 156(3): 997-1005 (doi: 10.1104/pp.111.175232).

19. Khan M.N., Siddiqui M.H., Mohammad F., Naeem M. Interactive role of nitric oxide and calcium chloride in enhancing tolerance to salt stress. Nitric Oxide, 2012, 27(4): 210-218 (doi: 10.1016/j.niox.2012.07.005).

20. Hadi M.R., Karimi N. The role of calcium in plants' salt tolerance. Journal of Plant Nutrition, 2012, 35(13): 2037-2054 (doi: 10.1080/01904167.2012.717158).

21. Manishankar P., Wang N., Köster P., Alatar A., Kudla J. Calcium signaling during salt stress and in the regulation of ion homeostasis. Journal of Experimental Botany, 69(17): 4215-4226 (doi: 10.1093/jxb/ery201).

22. Tan W., Meng Q.W., Brestic M., Olsovska K., Yang X. Photosynthesis is improved by exogenous calcium in heat-stressed tobacco plants. Journal of Plant Physiology, 2011, 168(17): 2063-2071 (doi: 10.1016/j.jplph.2011.06.009).

23. Huang D., Gong X., Liu Y., Zeng G., Lai C., Bashir H., Zhou L., Wang D., Xu P., Cheng M., Wan J. Effects of calcium at toxic concentrations of cadmium in plants. Planta, 2017, 245(5): 863-873 (doi: 10.1007/s00425-017-2664-1).

24. Zhang T., Yang J., Sun Y., Kang Y., Yang J., Qi Z. Calcium deprivation enhances non-selective fluid-phase endocytosis and modifies membrane lipid profiles in Arabidopsis roots. Journal of Plant Physiology, 2018, 226: 22-30 (doi: 10.1016/j.jplph.2018.04.002).

25. González-Fontes A., Navarro-Gochicoa M.T., Ceacero C.J., Herrera-Rodríguez M.B., Camacho-Cristybal J.J., Rexach J. Chapter 9 - Understanding calcium transport and signaling, and its use efficiency in vascular plants. In: Plant macronutrient use efficiency. Molecular and genomic perspectives in crop plants. M.A. Hossain, T. Kamiya, D.J. Burritt, L.-S.P. Tran, T. Fujiwara (eds.). Academic Press, 2017: 165-180 (doi: 10.1016/B978-0-12-811308-0.00009-0).

26. Krämer U., Talke I.N., Hanikenne M. Transition metal transport. FEBS Letters, 2007, 581(12): 2263-2272 (doi: 10.1016/j.febslet.2007.04.010). 